\title{
Pengaruh Model Pembelajaran Tipe Word Square Berbasis Kearifan Lokal terhadap Kompetensi Pengetahuan IPA
}

\author{
I Kt. Agus Suartika ${ }^{1 *}$, I Kt. Ardana ${ }^{2}$, I Wyn. Wiarta ${ }^{3}$ \\ ${ }^{123}$ Jurusan Pendidikan Guru Sekolah Dasar, FIP, Universitas Pendidikan Ganesha, Indonesia
}

\author{
A R T I C LEINFO \\ Article history: \\ Received 18 Desember \\ 2018 \\ Received in revised form \\ 30 Desember 2018 \\ Accepted 15 Januari 2019 \\ Available online 20 \\ Februari 2019 \\ Kata Kunci: \\ Kearifan Lokal, Kompetensi \\ Pengetahuan IPA, Word \\ Square \\ Keywords: \\ Local genius, Natural \\ science competence, Word \\ Square
}

\begin{abstract}
A B S T R A K
Penelitian ini bertujuan untuk mengetahui perbedaan yang signifikan kompetensi pengetahuan IPA antara kelompok siswa yang dibelajarkan melalui model pembelajaran tipe Word Square berbasis kearifan lokal dan kelompok siswa yang dibelajarkan melalui pembelajaran konvensional siswa kelas V SD Gugus Dewi Sartika Kecamatan Denpasar Timur Tahun Pelajaran 2017/2018. Jenis penelitian adalah penelitian eksperimen semu dengan rancangan nonequivalent control group design. Populasi dalam penelitian ini seluruh siswa kelas V SD Negeri di Gugus Dewi Sartika Kecamatan Denpasar Timur sebanyak 328 orang yang tersebar menjadi 9 kelas. Sampel penelitian adalah siswa kelas VA SDN 3 Kesiman sebagai kelompok eksperimen sebanyak 40 orang dan siswa kelas VB SDN 10 Kesiman sebagai kelompok kontrol sebanyak 42 orang yang diperoleh dengan teknik random sampling. Pengumpulan data menggunakan metode tes dengan bentuk tes objektif pilihan ganda biasa. Data dianalisis menggunakan uji-t(polled varians). Hasil penelitian menunjukan terdapat perbedaan yang signifikan kompetensi pengetahuan IPA antara kelompok siswa yang dibelajarkan melalui model pembelajaran tipe Word Square berbasis kearifan lokal dan kelompok siswa yang dibelajarkan melalui pembelajaran konvensional siswa kelas V SD Gugus Dewi Sartika Kecamatan Denpasar Timur Tahun Pelajaran 2017/2018. Adanya perbedaan yang signifikan menunjukan bahwa penerapan model pembelajaran tipe Word Square berbasis kearifan lokal berpengaruh terhadap kompetensi pengetahuan IPA.
\end{abstract}

\section{A B S T R A C T}

This research aimed to know the significant differences of natural science competence between the group of students who were taught by Word Square type model based on local genius and the group of students who were taught by convensional learning of fifth grade students of SD Negeri Gugus Dewi Sartika of Denpasar Timur subdistrict in academic year 2017/2018. Type of this research was quasi experimental research with non-equivalent control group design. The population of this research was all students of fifth grade students in SD Negeri Gugus Dewi Sartika Denpasar Timur subdistrict in academic year 2017/2018 amounted 328 students which scattered into 9 classes. The sample of this research were students of VA SD Negeri 3 Kesiman as an experimental group amounted 40 students and students of VB SD Negeri 10 Kesiman as a control group amounted 42 students has got by using random sampling technique. The data were collected by using the test method in form of usual multiple choice objective test.The data was analyzed by using t-test (polled varians). Result of the research shows that existence of significant differences shows that the implementation of Word Square type model based on local genius has an effect on natural science competence.

\footnotetext{
${ }^{1}$ Corresponding author.

E-mail addresses: kt.agus.suartika@undiksha.ac.id (I Kt. Agus Suartika)
} 


\section{Pendahuluan}

Pada era globalisasi seperti sekarang ini manusia dituntut untuk selalu mengikuti kemajuankemajuan ilmu pengetahuan yang terus berkembang. Kemajuan tersebut tidak bisa dihindari, melainkan harus berani menatap dan menyambutnya, bahkan masuk kedalam pelukannya tanpa harus kehilangan jati diri. Jati diri bangsa seperti ini harus dibina sejak dini dan berlanjut sepanjang hayat melalui pendidikan formal dan informal. Pendidikan memiliki peranan yang sangat penting terhadap perkembangan dan kemajuan suatu bangsa. Dengan pendidikan yang baik maka akan tercipta sumber daya manusia (SDM) yang berkualitas. Oleh karena itu, peningkatan kualitas pendidikan adalah tindakan yang secara terus menerus harus dilakukan demi tercapainya tujuan pendidikan nasional. Menurut Arni (2014) Keinginan semua guru adalah menjadi guru profesional, tetapi untuk meraihnya tidaklah mudah. Butuh pembelajaran dan usaha yang serius. Upaya mencerdaskan kehidupan bangsa dan mengembangkan kualitas manusia seutuhnya, adalah misi pendidikan yang menjadi tanggung jawab professional setiap guru. Guru tidak cukup hanya menyampaikan materi pengetahuan kepada siswa di kelas tetapi dituntut untuk meningkatkan kemampuan guna mendapatkan dan mengelola informasi yang sesuai dengan kebutuhan profesinya.

Dalam Undang-Undang Nomor 20 Tahun 2003 tentang Sistem Pendidikan Nasional dinyatakan bahwa "pendidikan adalah usaha sadar dan terencana untuk mewujudkan suasana belajar dan proses pembelajaran agar peserta didik secara aktif mengembangkan potensi dirinya untuk memiliki kekuatan spiritual keagamaan, pengendalian diri, kecerdasan, akhlak mulia serta keterampilan yang diperlukan dirinya, masyarakat, bangsa dan negara." Dunia pendidikan tidak terlepas dari proses pembelajaran. Belajar bukan merupakan suatu hasil atautujuan melainkan suatu proses. Belajar bukan hanya mengingat melainkan mengalami. Hasil belajar bukan suatu penguasaan hasil latihan melainkan pengubahan kelakuan (Hamalik, 2011). Dari penjelasan tersebut diharapkan dalam suatu pembelajaran individu dapat melalui proses belajar secara bermakna sehingga tujuan pembelajaran dapat tercapai. Kebermaknaan suatu proses pembelajaran dapat tercapai apabila konsep baru atau informasi baru dapat dikaitkan dengan konsep-konsep yang sudah ada. Agar tujuan pendidikan dapat tercapai dengan baik perlu adanya suatu pedoman dalam penyelenggaraan pendidikan. Dalam UU No. 20 Tahun 2003 tentang Sistem Pendidikan Nasional, dinyatakan bahwa kurikulum adalah seperangkat rencana dan pengaturan mengenai tujuan, isi dan bahan pelajaran serta cara yang digunakan sebagai pedoman penyelenggaraan kegiatan pembelajaran.

Kurikulum merupakan sebuah wadah yang akan menentukan arah pendidikan. Berhasil dan tidaknya sebuah pendidikan sangat bergantung dengan kurikulum yang digunakan. Oleh karena itu, pemerintah perlu mengembangkan dan menyempurnakan kurikulum yang sudah ada menjadi lebih baik lagi. Kurikulum pembelajaran yang berlaku di Indonesia saat ini adalah Kurikulum 2013. Fadlillah (2014:16) menyebutkan bahwa "Kurikulum 2013 adalah sebuah kurikulum yang dikembangkan untuk meningkatkan dan menyeimbangkan kemampuan soft skills dan hard skills yang berupa sikap, keterampilan, dan pengetahuan". Kurikulum 2013 merupakan pengembangan dan penyempurnaan kurikulum yang sudah ada sebelumnya. Selain itu, pembelajaran dalam Kurikulum 2013 lebih bersifat tematik integratif dalam beberapa mata pelajaran dan menggunakan pendekatan saintifik. Beberapa mata pelajaran yang terintegrasi dalam Kurikulum 2013, yaitu Ilmu Pengetahuan Alam (IPA), Seni Budaya dan Prakarya (SBdP), Bahasa Indonesia, Pendidikan Pancasila dan Kewarganegaraan (PPKn) dan Ilmu Pengetahuan Sosial (IPS).

Menurut Pindo (2018)IPA merupakan mata pelajaran yang sangat penting untuk dipelajari di tingkat SD, sebab membahas tentang peristiwaperistiwa yang terjadi di alam dan dekat dengan kehidupan peserta didik tersebut. Pendidikan IPA di sekolah dasar juga diharapkan dapat menjadi wahana peserta didik untuk mempelajari diri sendiri dan alam sekitar, serta prospek pengembangan lebih lanjut dalam menerapkannya di kehidupan sehari-hari. Proses pembelajaran IPA harus menekankan pada pemberian pengalaman secara langsung oleh peserta didik untuk mengembangkan kompetensi agar menjelajahi dan memahami alam sekitar, yang pada akhirnya mereka menemukan sendiri konsep materi pelajaran yang sedang dipelajarinya. Ilmu Pengetahuan Alam (IPA) merupakan salah satu mata pelajaran yang terintegrasi dalam Kurikulum 2013, termasuk pada jenjang sekolah dasar. IPA sebagai disiplin ilmu dan penerapannya dalam masyarakat membuat Pendidikan IPA menjadi sangat penting. Menurut Susanto (2015:167) "Sains atau IPA adalah usaha manusia dalam memahami alam semesta melalui pengamatan yang tepat pada sasaran serta menggunakan prosedur, dan dijelaskan dengan penalaran sehingga mendapatkan suatu kesimpulan". IPA sangat penting diberikan kepada siswa SD, karena melalui mata pelajaran ini siswa diajarkan untuk lebih mengenal tentang alam serta peristiwa-peristiwa yang terjadi di alam (Samatowa, 2011). Muatan materi IPA di SD seyogyanya dapat memupuk rasa ingin tahu siswa secara alamiah. Hal ini akan membantu mereka mengembangkan kemampuan bertanya dan mencari 
jawaban atas berdasarkan bukti serta mengembangkan cara berpikir ilmiah. Pendidikan IPA pada tingkat dasar akan dapat memberikan kontribusi yang signifikan pada seluruh proses pendidikan yang terjadi pada siswa. Ini disebabkan karena siswa SD kesehariannya selalu berhadapan dengan alam yang merupakan objek dari pendidikan IPA. Pembelajaran IPA akan lebih bermakna apabila dalam proses pembelajaran selalu dikaitkan dengan keadaan di lingkungan siswa. Dalam penelitian Muriana (2014) juga disebutkan bahwa proses pembelajaran di sekolah dasar memerlukan kiat atau metode tertentu agar materi lebih mudah dipahami siswa. Ini berarti bahwa apabila muatan materi pelajaran IPA diajarkan dengan cara yang tepat, maka akan menjadi suatu mata pelajaran yang menarik bagi siswa.

Berdasarkan hasil observasi yang dilakukan di kelas V SD Gugus Dewi Sartika Kecamatan Denpasar Timur Tahun Pelajaran 2017/2018 pada tanggal 9 sampai dengan 10 Januari 2018, khususnya pada mata pelajaran Ilmu Pengetahuan Alam (IPA) dapat diketahui bahwa kompetensi pengetahuan IPA siswa kelas V SD di Gugus Dewi Sartika Kecamatan Denpasar Timur Tahun Pelajaran 2017/2018 kurang optimal. Hal tersebut dilihat dari nilai raport siswa semester ganjil, dari 328 siswa yang mendapat nilai A (sangat baik) sebanyak 29 siswa, siswa yang mendapat nilai B (baik) sebanyak 136 siswa, siswa yang mendapat nilai C (cukup) sebanyak 160 siswa, dan siswa yang mendapat nilai D (kurang) sebanyak 3 siswa. Berdasarkan data yang diperoleh, 165 siswa atau 50,3\% siswa sudah mencapai hasil belajar sesuai yang diharapkan. Sedangkan, 162 siswa atau 49,7\% siswa belum mampu menunjukkan hasil belajar yang baik atau belum memperoleh predikat B (baik). Berkaitan dengan hal ini terdapat beberapa faktor yang mempengaruhi hal tersebut, diantaranya penggunaan model pembelajaran yang belum inovatif serta kurangnya pengaitan proses pembelajaran dengan kondisi di lingkungan sekitar siswa, khususnya nilainilai kearifan lokal. Selain itu, pemanfaatan media dalam proses pembelajaran masih jarang dipergunakan yang menyebabkan siswa kurang terlibat secara aktif dan cenderung merasa bosan dalam mengikuti proses pembelajaran sehingga siswa kurang memahami materi pelajaran yang diberikan oleh guru.

Setelah melakukan refleksi bersama guru, dirasakan oleh guru bahwa guru perlu menentukan strategi, pendekatan, model maupun media yang inovatif dengan cara memanfaatkan segala sesuatu yang berkaitan dengan kearifan lokal di lingkungan sekitar siswa agar proses pembelajaran menjadi lebih optimal. Dengan kondisi ini, guru membutuhkan kinerja yang lebih dalam meningkatkan pemahaman dan semangat siswa di dalam proses pembelajaran. Kegiatan pembelajaran harus mampu menghubungkan antara pengetahuan yang dimiliki oleh siswa dengan materi pelajaran IPA yang akan diajarkan. Oleh karena itu, dalam kegiatan pembelajaran diperlukan adanya model pembelajaran yang tepat dalam membelajarkan siswa.

Sebagai salah satu alternatif untuk mengatasi kelemahan-kelemahan yang dihadapi oleh guru SD di Gugus Dewi Sartika, peneliti mencoba menerapkan strategi pembelajaran untuk mengoptimalkan kompetensi pengetahuan IPA siswa. Strategi tersebut adalah model pembelajaran kooperatif tipe Word Square berbasis kearifan lokal. Model pembelajaran Word Square adalah "model yang memadukan kemampuan menjawab pertanyaan dengan kejelian dalam mencocokan jawaban pada kotak-kotak jawaban" (Kurniasih dan Sani, 2017:97). Proses pembelajaran dengan menggunakan model Word Square dapat mendorong pemahaman siswa terhadap materi pelajaran, menciptakan suasana yang menyenangkan karena pembelajaran berupa permainan. Menurut Herwandannu (2018) model pembelajaran kooperatif merupakan jenis belajar yang dilakukan secara bentuk kelompok kecil dalam pembelajaran dengan tujuan agar siswa mampu berkerja sama dengan anggota kelompok lainnya. Model pembelajaran Word Square merupakan model yang bertujuan untuk melatih ketelitian dan kritis dalam menentukan jawaban. Menurut Putri (2017) model pembelajaran Word Square termasuk salah satu model pembelajaran yang memudahkan guru serta siswa dalam penerapannya ketika proses pembelajarannya. Selain itu, tidak terlalu banyak memotong waktu yang sudah ditentukan. Penggunaan model pembelajaran Word Square mampu memberikan hasil belajar siswa yang lebih maksimal dibandingkan dengan modelmodel pembelajaran yang lain. Model pembelajaran kooperatif tipe Word Square yang awalnya berdiri sendiri akan disisipkan dengan nilai-nilai kearifan lokal yang ada di lingkungan sekitar siswa. Wikantiyoso (2009:7) menyebutkan, kearifan lokal merupakan perilaku positif manusia dalam berhubungan dengan alam dan lingkungan sekitarnya, yang dapat bersumber dari nilai agama adat istiadat, petuah nenek moyang atau budaya setempat, yang terbangun secara alamiah dalam suatu komunitas masyarakat untuk beradaptasi dengan lingkungan sekitarnya. Menurut Udayana (2009:17) "konsep local genius, yang kemudian dialih bahasa indonesiakan menjadi kearifan lokal pada dasarnya adalah ciri kebudayaan suatu masyarakat/bangsa yang merupakan akumulasi pengalaman masa lalu yang bertahan hingga kini". Selain itu, Suja (2010:2) menyatakan bahwa "kearifan lokal merupakan bagian dari kebudayaan yang sudah mentradisi, menjadi milik kolektif, dan bersifat fungsional untuk memecahkan masalah, setelah melewati pengalaman dalam dimensi ruang dan waktu secara berkelanjutan". Berdasarkan beberapa pendapat tersebut dapat disimpulkan bahwa kearifan lokal merupakan bagian dari kebudayaan yang sudah mentradisi dan terbangun secara alamiah dalam suatu komunitas masyarakat/bangsa yang merupakan 
akumulasi pengalaman masa lalu yang bertahan hingga kini. Nilai-nilai kearifan lokal sejalan dengan muatan materi IPA yang mempelajari gejala-gejala yang ada di alam dengan tidak melupakan kebesaran dan kekuasaan pencipta alam semesta sehingga siswa akan mampu menata hubungan yang harmonis dengan Tuhan, manusia, dan lingkungannya (nilai kearifan Tri Hita Karana). Sehingga tidak menutup kemungkinan untuk mengintegrasikan nilai-nilai kearifan lokal yang ada di lingkungan siswa ke dalam muatan materi IPA (Ardana, 2015).

Untuk mewujudkan hal tersebut, pembelajaran harus berlangsung secara konstruktivis (membangun). Maka dari itu diperlukan rancangan kegiatan pembelajaran di sekolah yang tidak terlepas dari kehidupan nyata siswa sesuai kearifan lokal yang ada di lingkungannya. Penelitian ini dilaksanakan di SD Gugus Dewi Sartika, Kecamatan Denpasar Timur dengan tujuan untuk mengetahui perbedaan yang signifikan kompetensi pengetahuan IPA antara kelompok siswa yang dibelajarkan melalui model pembelajaran tipe Word Square berbasis kearifan lokal dan kelompok siswa yang dibelajarkan melalui model pembelajaran konvensional pada siswa kelas V SD Gugus Dewi Sartika Denpasar Timur Tahun Pelajaran 2017/2018.

\section{Metode}

Jenis penelitian yang digunakan dalam penelitian ini adalah penelitian kuantitatif dengan desain eksperimental yaitu eksperimen semu (quasi eksperiment). Jenis penelitian eksperimen semu dipilih karena peneliti tidak sepenuhnya dapat mengontrol variabel-variabel luar yang mempengaruhi pelaksanaan eksperimen (Sugiyono, 2016). Selain itu penelitian eksperimental semu bertujuan untuk memperoleh informasi yang dapat diperoleh dengan eksperimen yang sebenarnya dalam keadaan yang tidak memungkinkan untuk mengontrol atau memanipulasikan semua variabel yang relevan (Narbuko dan Achmadi, 2007). Bentuk desain eksperimen yang digunakan adalah nonequivalent control group design. Dalam desain ini terdapat dua kelompok, yaitu kelompok eksperimen dan kelompok kontrol.Kedua kelompok tersebut diberikan pre-test dan post-test. Pre-test diberikan pada kelompok eksprimen dan kelompok kontrol sebagai penyetaraan kelompok. Setelah diberikan pre-test, Pada kelompok eksperimen diberikan perlakuan berupa model pembelajaran kooperatif tipe Word Square berbasis kearifan lokal, sedangkan pada kelompok kontrol tidak diberikan perlakuan atau dengan kata lain dibelajarkan dengan pembelajaran konvensional melalui pendekatan scientific. Kemudian, post-test dilakukan pada akhir penelitian dan diberikan pada kelompok eksperimen dan kelompok kontrol untuk memperoleh data kompetensi pengetahuan IPA.

Populasi penelitian ini adalah seluruh siswa kelas V SD Negeri di Gugus Dewi Sartika Kecamatan Denpasar Timur tahunpelajaran 2017/2018, yaitu sebanyak 328 siswa. Berdasarkan karakteristik populasi dan tidak bisa dilakukannya pengacakan individu, maka dalam penelitian ini, sampel dari populasi diambil denganrandom sampling yang dirandom kelasnya. Menurut Narbuko dan Achmadi (2013:111), "teknik random sampling adalah teknik pengambilan sampel dimana semua individu dalam populasi baik secara sendiri-sendiri atau bersama-sama diberi kesempatan yang sama untuk dipilih menjadi anggota sampel". Pengambilan sampel dilakukan dengan diundi secara acak. Berdasarkan hasil pengundian maka yang menjadi kelas eksperimen adalah kelas V A SD Negeri 3 Kesiman dengan jumlah 40 siswa dan yang menjadi kelas kontrol adalah kelas V B SD Negeri 10 Kesiman dengan jumlah 42 siswa.

Metode pengumpulan data dalam penelitian ini menggunakan metode tes. Data yang dikumpulkan dalam penelitian ini adalah data kompetensi pengetahuan IPA siswa kelas V SD Gugus Dewi Sartika Kecamatan Denpasar Timur tahun ajaran 2017/2018. Tes yang digunakan untuk mengukur kompetensi pengetahuan IPA berupa tes objektif dalam bentuk pilihan ganda biasa yang meliputi 4 pilihan jawaban (a, b, c atau d). Setiap item diberikan skor 1 bila siswa menjawab dengan benar (jawaban disesuaikan dengan kunci jawaban) dan skor 0 bila siswa menjawab salah. Skor setiap jawaban dijumlahkan dan jumlah tersebut menjadi skor variabel kompetensi pengetahuan IPA yang bergerak dari kisaran 0 - 50. 0 merupakan skor minimal dan 50 merupakan skor maksimal tes kompetensi pengetahuan IPA. Skor yang diperoleh siswa selanjutnya dikonversikan menjadi nilai dengan membagi skor yang diperoleh siswa dengan skor maksimal kemudian dikalikan 100.

Sebelum memberikan soal tes penguasaan kompetensi pengetahuan IPA kepada kelompok eksperimen dan kelompok kontrol, sebelumnya soal terlebih dahulu divalidasi secara teoritis dengan menggunakan kisi-kisi serta dikonsultasikan pada ahli.Kemudian tes diujicobakan kepada responden sebanyak 42 orang siswa. Dari hasil uji instrumen yang meliputi uji validitas, uji daya beda, uji tingkat kesukaran, dan uji reliabilitasdari 50 butir tes diperoleh 30 butir tes yang dinyatakan layak digunakan sebagai instrumen dalam penelitian ini.

Metode analisis data yang digunakan dalam penelitian ini adalah analisis statistik deskriptif dan analisis statistik inferensial. Statistik deskriptif adalah statistik yang digunakan untuk menganalisis data 
dengan cara mendeskripsikan atau menggambarkan data yang telah terkumpul sebagaimana adanya tanpa bermaksud membuat kesimpulan yang berlaku untuk umum atau generalisasi (Sugiyono, 2016:207). Teknik analisis data deskriptif dalam penelitian ini digunakan untuk mendeskripsikan data kompetensi pengetahuan IPA siswa yang dibelajarkan dengan model pembelajaran kooperatif tipe Word Square berbasis kearifan lokal dan kompetensi pengetahuan IPA siswa yang dibelajarkan dengan pembelajaran konvensional dengan menggunakan pendekatan saintifik. Data penguasaan kompetensi pengetahuan IPA siswa kelompok eksperimen dan kelompok kontrol disajikan secara deskriptif untuk mengetahui nilai rata-rata (mean), varians, dan standar deviasi.

Statistik inferensial, (sering juga disebut statistik induktif atau statistik probabilitas), adalah teknik statistik yang digunakan untuk menganalisis data sampel dan hasilnya diberlakukan untuk populasi. Statistik inferensial dalam penelitian ini terdiri dari uji prasyarat analisis dan uji hipotesis. Uji prasyarat analisis dilakukan dengan uji normalitas sebaran data dan uji homogenitas varians. Uji normalitas sebaran data dilakukan dengan rumus Chi-kuadrat $\left(\mathrm{X}^{2}\right)$ dengan kriteria pengujian jika $X^{2}$ hit $\leq X^{2}$ tabel dengan taraf signifikasi $5 \%(\mathrm{dk}=$ jumlah kelas dikurangi parameter, dikurangi 1$)$, maka $\mathrm{H}_{\mathrm{o}}$ diterima yang berarti data berdistribusi normal.Uji homogenitas varians dilakukan dengan uji Fkriteria pengujian pada taraf signifikansi $5 \%$ dengan dk untuk pembilang $=\mathrm{n}_{1}-1 \mathrm{dan}$ dk untuk penyebut $=\mathrm{n}_{2}-1$, jika $\mathrm{F}_{\text {hitung }}<\mathrm{F}_{\text {tabel }}$ maka varians kedua kelompok data adalah homogen.

Apabila data yang diperoleh sudah memenuhi prasyarat uji normalitas sebaran data dan uji homogenitas varians maka analisis data yang digunakan untuk menguji hipotesis adalah statistik parametrik. Analisis statistik yang digunakan untuk menguji hipotesis penelitian ini adalah uji beda mean (uji- $\mathrm{t}$ ) dengan rumus polled varians dengan kriteria jika harga $\mathrm{t}_{\text {hitung }} \leq \mathrm{t}_{\text {tabel}}$, maka $\mathrm{H}_{0}$ yang berbunyi tidak terdapat perbedaan yang signifikan kompetensi pengetahuan IPA antara kelompok siswa yang dibelajarkan melalui model pembelajaran kooperatif tipe Word Square berbasis kearifan lokal dan kelompok siswa yang dibelajarkan melalui pembelajaran konvensional pada kelas V SD Gugus Dewi Sartika Kecamatan Denpasar Timur diterima dan $\mathrm{H}_{\mathrm{a}}$ ditolak, dan jika harga $\mathrm{t}_{\text {hitung }}>\mathrm{t}_{\text {tabel }}$ maka $\mathrm{H}_{\mathrm{o}}$ ditolak dan $\mathrm{H}_{\mathrm{a}}$ diterima pada taraf signifikan $5 \%$ dengan $\mathrm{dk}=\mathrm{n}_{1}+\mathrm{n}_{2}-2$.

\section{Hasil dan Pembahasan}

Berdasarkan hasil post-test terhadap 40 orang siswa di kelas eksperimen pada siswa kelas V A di SD Negeri 3 Kesiman Gugus Dewi Sartika Kecamatan Denpasar Timur Tahun Pelajaran 2017/2018 yang di belajarkan melalui pembelajaran kooperatif tipe Word Square berbasis kearifan lokal, menunjukan bahwa nilai tertinggi yang diperoleh siswa adalah 93 dan nilai terendah yang diperoleh siswa adalah 40 . Berdasarkan sebaran data tersebut maka diperoleh rata-rata (mean) sebesar 73,70 yang termasuk kriteria cukup setelah dikonversikan ke dalam PAP skala lima dengan varians 162,42 dan standar deviasi 12,74. Data penguasaan kompetensi pengetahuan IPA kelompok eksperimen, dapat disajikan histogram sebagai berikut.

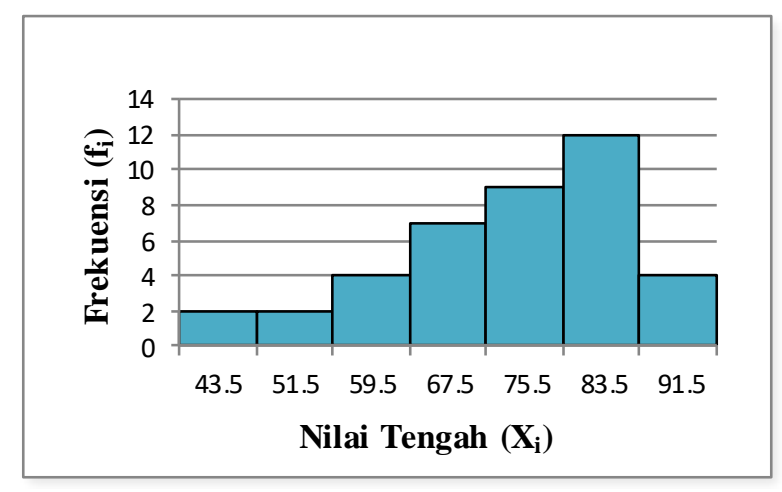

Gambar 1. Histogram Kompetensi Pengetahuan IPA

Berdasarkan histogram tersebut dapat dideskripsikan bahwa frekuensi pada kelas interval pertama dengan nilai tengah 43,5 sebanyak 2 orang, frekuensi pada kelas interval kedua dengan nilai tengah 51,5 sebanyak 2 orang, frekuensi pada kelas interval ketiga dengan nilai tengah 59,5 sebanyak 4 orang, frekuensi pada kelas interval keempat dengan nilai tengah 67,5 sebanyak 7 orang, frekuensi pada kelas interval kelima dengan nilai tengah 75,5 sebanyak 9 orang, frekuensi pada kelas interval keenam dengan nilai tengah 83,5 sebanyak 12 orang, dan frekuensi pada kelas interval ketujuh dengan nilai 
tengah 91,5 sebanyak 4 orang. Kelas interval dengan frekuensi tertinggi terletak pada nilai tengah 83,5 dan kelas interval dengan frekuensi terendah terletak pada nilai tengah 43,5 dan 51,5.

Berdasarkan hasil post-test terhadap 42 orang siswa di kelas kontrol pada siswa kelas V B di SD Negeri 10 Kesiman Gugus Dewi Sartika Kecamatan Denpasar Timur Tahun Pelajaran 2017/2018 yang di belajarkan melalui pembelajaran konvensional, menunjukan bahwa nilai tertinggi yang diperoleh siswa adalah 93 dan nilai terendah yang diperoleh siswa adalah 30. Berdasarkan sebaran data tersebut maka diperoleh rata-rata (mean) sebesar 63,07 yang termasuk kriteria kurang setelah dikonversikan ke dalam PAP skala lima dengan varians 227,18 dan standar deviasi 15,07. Data penguasaan kompetensi pengetahuan IPA kelompok kontrol, dapat disajikan histogram sebagai berikut.

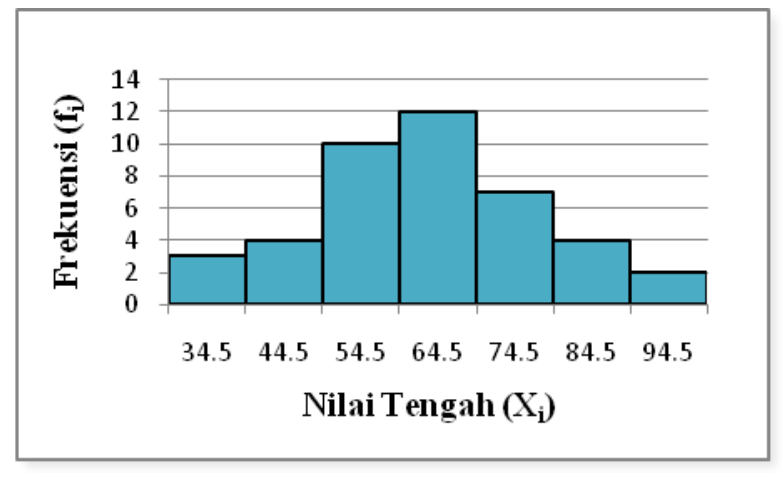

Gambar 2. Histogram Kompetensi Pengetahuan IPA

Berdasarkan histogram tersebut dapat dideskripsikan bahwa frekuensi pada kelas interval pertama dengan nilai tengah 34,5 sebanyak 3 orang, frekuensi pada kelas interval kedua dengan nilai tengah 44,5 sebanyak 4 orang, frekuensi pada kelas interval ketiga dengan nilai tengah 54,5 sebanyak 10 orang, frekuensi pada kelas interval keempat dengan nilai tengah 64,5 sebanyak 12 orang, frekuensi pada kelas interval kelima dengan nilai tengah 74,5 sebanyak 7 orang, frekuensi pada kelas interval keenam dengan nilai tengah 84,5 sebanyak 4 orang, dan frekuensi pada kelas interval ketujuh dengan nilai tengah 94,5 sebanyak 2 orang. Kelas interval dengan frekuensi tertinggi terletak pada nilai tengah 83,5 dan kelas interval dengan frekuensi terendah terletak pada nilai tengah 94,5.

Sebelum dilaksanakan pengujian hipotesis terlebih dahulu dilakukan uji prasyarat analisis dengan uji normalitas dan uji homogenitas. Berdasarkan hasil uji prasyarat, yaitu normalitas dan homogenitas menunjukan data berdistribusi normal dan homogen. Uji normalitas sebaran data bertujuan untuk mengetahui sebaran data berdistribusi normal atau tidak sebelum dilakukan uji hipotesis. Berdasarkan perhitungan uji normalitas data penguasaan kompetensi pengetahuan IPA siswa kelompok eksperimen diperoleh nilai $\chi^{2}$ hitung $=4,202$ sedangkan untuk taraf signifikan $5 \%$ dan derajat kebebasan $(\mathrm{dk})=5$ diperoleh $\chi_{\text {tabel }}^{2}=11,070$ Karena $\chi^{2}$ hitung $=4,202<\chi^{2}$ tabel $=11,070$, sehingga data kompetensi pengetahuan IPA siswa kelompok eksperimen berdistribusi normal.

Berdasarkan perhitungan uji normalitas data penguasaan kompetensi pengetahuan IPA siswa kelompok kontrol diperoleh nilai $\chi^{2}$ hitung $=5,419$ sedangkan untuk taraf signifikan 5\% dan derajat kebebasan $(\mathrm{dk})=5$ diperoleh $\chi^{2}$ tabel $=11,070$ Karena $\chi^{2}$ hitung $=5,419<\chi^{2}$ tabel $=11,070$, sehingga data kompetensi pengetahuan IPA siswa kelompok kontrol berdistribusi normal.

Pengujian homogenitas varians antar kelompok dimaksudkan untuk meyakinkan bahwa perbedaan yang diperoleh dalam uji-t benar-benar berasal dari perbedaan antar kelompok bukan disebabkan oleh perbedaan di dalam kelompok.Begitu pula dengan hasil uji homogenitas menggunakan rumus uji $\mathrm{F}$, diperoleh $\mathrm{F}_{\text {hitung }}=1,40$, hasil ini kemudian dibandingkan dengan harga $\mathrm{F}_{\text {tabel }}$ dengan derajat kebebasan pembilang 42-1 = 41 dan derajat kebebasan penyebut 40-1 = 39 dengan taraf signifikan 5\%, sehingga diperoleh $F_{\text {tabel }}=1,69$. Karena harga $F_{\text {hitung }}<F_{\text {tabel }}(1,40<1,69)$, maka varians datakompetensi pengetahuan IPA antara siswa kelompok eksperimen dan kelompok kontrol adalah homogen.

Sedangkan dari pengujian hipotesis diketahui bahwa hasil perhitungan uji-t dengan rumus polled varians diperoleh $t_{\text {hitung }}=3,434$ dan $t_{\text {tabel }}$ pada taraf signifikansi $5 \%$ dengan derajat kebebasan $(\mathrm{dk})=40+$ $42-2=80$ diperoleh $t_{\text {tabel }}=2,000$. Sehingga, $t_{\text {hitung }}>t_{\text {tabel }}$ yaitu 3,434>2,000 sehingga $H_{0}$ ditolak dan Ha diterima. Artinya, terdapat perbedaan yang signifikan kompetensi pengetahuan IPA antara kelompok siswa yang dibelajarkan melalui pembelajaran kooperatif tipe Word Square berbasis kearifan lokal dan kelompok siswa yang dibelajarkan melalui pembelajaran konvensional siswa kelas V SD Negeri Gugus Dewi Sartika Kecamatan Denpasar Timur Tahun Pelajaran 2017/2018. 
Berdasarkan hasil post-test yang diberikan kepada kedua kelompok sampel penelitian, diperoleh hasil perhitungan analisis data yang menunjukan bahwa nilai rata-rata dari kelompok siswa yang dibelajarkan melalui model pembelajran kooperatif tipe Word Square berbasis kearifan lokal memperoleh nilai rata-rata sebesar $(\bar{X}=73,70)$, sedangkan kelompok siswa yang dibelajarkan melalui pembelajaran konvensional memperoleh nilai rata-rata sebesar $(\bar{X}=63,07)$. Jadi nilai rata-rata dari kedua kelompok memiliki perbedaan sebesar 10,63. Ini menunjukan bahwa nilai rata-rata kelompok eksperimen yang dibelajarkan melalui model pembelajran kooperatif tipe Word Square berbasis kearifan lokal lebih tinggi dibandingkan dengan nilai rata-rata kelompok kontrol yang dibelajarkan melalui pembelajaran konvensional. Setelah dikonversikan ke PAP skala lima diperoleh analisiskompetensi pengetahuan IPA pada kelompok siswa yang dibelajarkan melalui model pembelajran kooperatif tipe Word Square berbasis kearifan lokal yang memperoleh nilai rata-rata sebesar $\bar{X}=73,70$ yaitu tingkat kemampuan siswa termasuk kategori cukup, sedangkan kompetensi pengetahuan IPA pada kelompok siswa yang dibelajarkan melalui pembelajaran konvensional yang memperoleh nilai rata-rata sebesar $\bar{X}=63,07$ yaitu tingkat kemampuan siswa termasuk kategori kurang.

Model pembelajaran kooperatif tipe Word Square berbasis kearifan lokal merupakan model pembelajaran yang memadukan kemampuan siswa dalam menjawab pertanyaan dan kejelian dalam mencocokan jawaban pada kotak-kotak jawaban. Proses pembelajaran dengan menggunakan model pembelajaran kooperatif tipe Word Square berbasis kearifan lokal dapat mendorong pemahaman siswa terhadap materi pelajaran, melatih siswa untuk disiplin, merangsang siswa untuk berpikir secara efektif, bersikap kritis dan teliti, serta dapat menciptakan suasana yang menyenangkan karena pembelajaran berupa permainan. Dalam proses pembelajaran juga dikaitkan dengan nilai-nilai kearifan lokal yang ada di lingkungan sekitar siswa khususnya konsep Tri Hita Karana sehingga pembelajaran menjadi lebih bermakna.

Hasil temuan pada penelitian ini mendukung hasil penelitian sebelumnya yang disampaikan oleh Sukandheni (2014) yang menyatakan bahwa model pembelajaran kooperatif tipe Word Square berbasis lingkungan berpengaruh positif dan signifikan terhadap hasil belajar IPA pada kelas V Gugus Budi Utomo Denpasar Timur Tahun Pelajaran 2013/2014. Penelitian lain yang memiliki kesaman dengan penelitian ini adalah penelitian yang dilakukan oleh Wahyu (2017) yang menyatakan bahwa terdapat perbedaan yang signifikan hasil belajar Bahasa Indonesia antara kelompok siswa yang dibelajarkan dengan model pembelajaran kooperatif tipe Word Square dan kelompok siswa yang dibelajarkan dengan model pembelajaran konvensional pada siswa kelas V SD di Gugus I Kecamatan Kediri Kabupaten Tabanan Tahun Pelajaran 2016/2017. Selain itu penelitian ini juga mendukung penelitian yang dilakukan oleh Sumayasa (2016) yang menunjukan bahwa model pembelajaran Word Square berbasis kearifan lokal catur marga dengan assesment portofolio berpengaruh positif dan signifikan terhadap hasil belajar IPS siswa kelas IV SD semester II di Gugus I Kecamatan Sukasada Tahun Pelajaran 2015/2016. Melalui penjelasan tersebut, dapat disimpulkan bahwa model pembelajaraan kooperatif tipe Word Square berbasis kearifan lokal berpengaruh terhadap kompetensi pengetahuan IPA siswa kelas V SD Gugus Dewi Sartika Kecamatan Denpasar Timur Tahun Pelajaran 2017/2018.

\section{Simpulan dan Saran}

Berdasarkan hasil analisis data kompetensi pengetahuan IPA diperoleh $t_{\text {hitung }}=3,434$ sedangkan nilai tabel pada taraf signifikan $5 \%$ dengan derajat kebebasan $(\mathrm{dk}=40+42-2=80)$ adalah 2,000 . Karena $t_{\text {hitung }}>t_{\text {tabel }}(3,434>2,000)$ maka $\mathrm{H}_{0}$ yang berbunyi tidak terdapat perbedaan yang signifikan kompetensi pengetahuan IPA kelompok siswa yang dibelajarkan melalui model pembelajaran kooperatif tipe Word Square berbasis kearifan lokal dan kelompok siswa yang dibelajarkan melalui pembelajaran konvensional pada siswa kelas V SD Gugus Dewi Sartika Kecamatan Denpasar Timur Tahun Pelajaran 2017/2018 ditolak dan $\mathrm{H}_{\mathrm{a}}$ yang berbunyi terdapat perbedaan yang signifikan kompetensi pengetahuan IPA kelompok siswa yang dibelajarkan melalui model pembelajaran kooperatif tipe Word Square berbasis kearifan lokal dan kelompok siswa yang dibelajarkan melalui pembelajaran konvensional pada siswa kelas V SD Gugus Dewi Sartika Kecamatan Denpasar Timur Tahun Pelajaran 2017/2018 diterima. Nilai rata-rata kompetensi pengetahuan IPA kelompok eksperimen $(\bar{X}=73,70)$ lebih dari rata-rata kompetensi pengetahuan IPA kelompok kontrol $(\bar{X}=63,07)$. Sehingga dapat disimpulkan bahwa terdapat perbedaan yang signifikan kompetensi pengetahuan IPA kelompok siswa yang dibelajarkan melalui model pembelajaran kooperatif tipe Word Square berbasis kearifan lokal dan kelompok siswa yang dibelajarkan melalui pembelajaran konvensional pada siswa kelas V SD Gugus Dewi Sartika Kecamatan Denpasar Timur Tahun Pelajaran 2017/2018. 
Berdasarkan hasil temuan penelitian yang diperoleh, disarankan kepada guru agar lebih kreatif dan inovatif untuk memfasilitasi siswa dalam pembelajaran berupa sumber belajar dan kesempatan besar kepada siswa dalam pembelajaran dengan menggunakan model pembelajaran kooperatif tipe Word Squareberbasis kearifan lokal sehingga tercipta pembelajaran yang menyenangkan dan bermakna bagi siswa. Selain itu, kepala sekolah hendaknya dapat menggunakan hasil penelitian ini sebagai pendukung sumber belajar guru untuk menunjang pembelajaran sehingga siswa semakin termotivasi untuk belajar sehingga kepala sekolah mampu meningkatkan mutu sekolah melalui peningkatan kualitas dan hasil belajar siswa. Kepada peneliti lain disarankan agar dapat memanfaatkan hasil penelitian ini sebagai kajian penelitian relevan sebagai penunjang penelitian selanjutnya dengan kajian yang lebih luas dan mendalam mengenai model pembelajaran kooperatif tipe Word Square berbasis kearifan lokal dalam kaitannya dengan hasil belajar baik kompetensi pengetahuan, sikap, maupun keterampilan.

\section{Daftar Rujukan}

Ardana, I Ketut. (2015). "Implementasi Model Pembelajaran Tematik Berbasis Kearifan Lokal Untuk Meningkatkan Hasil Belajar IPA Mahasiswa Kelas E Semester II PGSD UPP II Denpasar". Jurnal Ilmiah Fakultas Ilmu Pendidikan Universitas Pendidikan Ganesha, Edisi 22, Desember 2015 (hlm. 83-102). ISSN : 1829 - 877X.

Arni Masita. 2014. Meningkatkan Hasil Pembelajaran IPA Melalui Strategi Pembelajaran Induktif Siswa Kelas IV SDN 6 Watuoge. Jurnal Kreatif Tadulako Online Vol. 5 No. 5 Hal. 93-107. http://jurnal.untad.ac.id/jurnal/index.php/JKTO/article/view/12211. Diakses pada Tanggal 7 Maret 2018.

Fadlilah. 2014. Implementasi Kurikulum 2013 Dalam Pembelajaran SD/MI, SMP/MTs, \& SMA/MA. Yogyakarta: Arr-Ruzz Media.

Hamalik, Oemar. 2011. Proses Belajar Mengajar. Jakarta: PT Bumi Aksara.

Herwandannu, Brili. 2018. Penerapan Model Pembelajaran Word Square untuk Menigkatkan Hasil Belajar IPS Siswa Kelas 3 SDN 2 Slempit Kedamean Gresik. JPGSD, Vol. 06 No. 12 halaman 2201-2210. http://jurnalmahasiswa.unesa.ac.id/index.php/. Diakses pada Tanggal 7 Maret 2018.

Kurniasih, Imas dan Berlin Sani. 2017. Ragam Pengembangan Model Pembelajaran. Jakarta: Kata Pena.

Muriana, Dewa Gede Alit. 2014. “Pengaruh Model Pembelajaran Word Square Terhadap Hasil Belajar IPA Siswa Kelas IV SD Desa Tista Tahun Pelajaran 2013/2014". Jurnal Mimbar PGSD Universitas Pendidikan Ganesha Jurusan PGSD, Volume 2, Nomor 1 (hlm 1-10). Tersedia pada https://download.portalgaruda.org (diakses pada tanggal 7 Maret 2018).

Narbuko, Cholid dan Abu Achmadi. 2013. Metodologi Penelitian. Jakarta: PT Bumi Aksara.

Pindo Hutauruk, Rinci Simbolon. 2018. Meningkatkan Hasil Belajar Siswa dengan Alat Peraga pada Mata Pelajaran IPA Kelas IV SDN Nomor 14 Simbolon Purba. SEJ (School Education Journal) Vol. 8 No 2 Hal.121-129. https://jurnal.unimed.ac.id/2012/index.php/. Diakses pada Tanggal 7 Maret 2018.

Putri, Awanda Devina. 2017. Pengaruh Model Pembelajaran Word Square terhadap Kemampuan Menjelaskan Energi Alternatif dan Cara Penggunaannya Semester 2 Kelas IV SDN Burengan 2 Kota Kediri TA 2015/2016. Pedagogia Vol. 01 No. 11 Hal. 2-8. http://simki.unpkediri.ac.id/mahasiswa/file_artikel/2017/. Diakses pada Tanggal 7 Maret 2018.

Samatowa, Usman. 2011. Pembelajaran IPA di Sekolah Dasar. Jakarta: Indeks.

Sugiyono. 2016. Metode Penelitian Pendidikan Pendekatan Kuantitatif, Kualitatif, Dan R\&D. Cetakan Ke-23. Bandung: Alfabeta.

Suja, I Wayan. 2010. Kearifan Lokal Sains Asli Bali. Surabaya: Paramita. 
Susanto, Ahmad. 2015. Teori Belajar Dan Pembelajaran Di Sekolah Dasar. Cetakan ke-3. Jakarta: Prenadamedia Group.

Udayana, Dewa Gede Alit. 2009. Tumpek Wariga Kearifan Lokal Bali Untuk Pelestarian Sumber Daya Tumbuh-tumbuhan. Surabaya: Paramita.

Undang-undang Nomor 20 Tahun 2003 tentang Sistem Pendidikan Nasional.2003.Jakarta: Depdiknas.

Wikantiyoso. 2009. Kearifan Lokal dalam Perencanaan dan Perancangan Kota untuk Mewujudkan Arsitektur Kota yang Berkelanjutan. Edisi Pertama. Malang: Group Konservasi Arsitektur dan Kota Jurusan Teknik Arsitektur Universitas Merdeka Malang. 